\title{
D. R. Congo: Explaining Peace Building Failures, 2003-2006
}

\section{Séverine Autesserre}

\begin{abstract}
As a corrective to the emphasis on national and international reconciliation during peace building processes, I develop here a conceptual analysis of the dynamics of violence during the transition from war to peace and democracy in the Democratic Republic of Congo between 2003 and 2006. I locate the sources, at the local, national, and regional levels, of continued local violence during this transition. Through an analysis of the situation in the provinces of North Kivu and North Katanga, I illustrate how local dynamics interacted with the national and regional dimensions of the conflict. I demonstrate that, after a national and regional settlement was reached, some local conflicts over land and political power increasingly became self-sustaining, autonomous, and disconnected from the national and regional tracks. Thus, peace building action was required not only at the national and regional levels but also locally.
\end{abstract}

Cet article plaide pour une correction de l'attention exclusive portée à la réconciliation nationale et régionale lors des processus de paix. Je développe une analyse conceptuelle des mécanismes de la violence durant les trois années officiellement consacrées à la transition de la guerre à la paix et à la démocratie en République Démocratique du Congo (de 2003 à 2006). J'identifie, au niveau local, national et régional, les raisons pour lesquelles la violence a perduré localement au cours de cette période. J'analyse la situation dans les provinces du Nord Kivu et du Nord Katanga pour illustrer l'interaction entre les mécanismes de la violence situés à ces différents niveaux. Je démontre que, après la signature d'accords de paix nationaux et régionaux, certains conflits locaux portant sur les terres et le pouvoir politique se sont progressivement dissociés des processus nationaux et régionaux et sont devenus autonomes. Les programmes de résolution de conflits auraient donc du adresser les sources de tensions au niveau local tout autant que les problèmes nationaux et régionaux.

A year after the war in the Democratic Republic of Congo officially ended on 30 June 2003, more than one thousand civilians continued to die every day. Most of the deaths were caused by disease and malnutrition and could have been prevented if outbursts of violence had not impeded access to humanitarian aid, especially in the east (International Rescue Committee, 2004). In April 2004, for example, the United Nations (UN) Office for the Coordination of Humanitarian Affairs wrote the following situation report:

The security situation was the most worrying this month in North-Kivu, South-Kivu and Katanga Provinces in the Eastern region of the Democratic Republic of Congo ... As a consequence of the fighting and increased tension in these three regions, approximately 3035,000 people were estimated displaced over the course of this month. In addition to the displacement, [the UN Office for the Coordination of Humanitarian Affairs] continued to 
receive reports of massacres, cannibalism, rapes, looting, extortion and other serious violations of human rights being committed by various armed groups, leaving questions as to whether or not the protection situation for civilians living in [the Congo] has improved since the war officially ended last year.

Even though the situation improved somewhat in 2005 and 2006, similar reports of tensions and local hostilities could be found in all weekly and monthly UN humanitarian situation reports covering the Congolese transition from war to peace and democracy (June 2003 - December 2006). What were the reasons for the continuation of such a high level of violence?

In June 2003, a settlement seemed to have been reached at the regional and national levels. The foreign troops that withdrew from the Congo in 2002 and 2003 officially remained out of Congolese territory. Normal diplomatic ties, including the exchange of ambassadors, resumed between former enemies. Important developments also took place at the national level, such as the official reunification of the country, the formation of a unified government, the preparation for democratic elections, and a progressive integration of the different armed groups into a single national army.

However, local conflict - at the level of the village, the district, or the community persisted in the eastern Congo. Political, economic, and social antagonisms generated frequent massacres, massive human rights violations, and population displacement. Although some progress was made compared to the situation during the war, a number of areas in the eastern Congo remained very unsafe, and many Congolese continued to suffer from violence waged by one of the armed groups still active. Why did the national and regional settlements fail to effect peace at the local level?

Many of the international actors I interviewed, especially high-ranking diplomats and UN staff members, do not believe that local causes played a decisive role in sustaining national and regional violence during the war and in the post-war period. During the transition, diplomats, UN staff, and many non-governmental organisations worked mostly on the national and regional cleavages, mediating among, and when necessary putting pressure on, the main Congolese, Rwandan, and Ugandan political and military leaders. Their role at the local level was often nonexistent (Autesserre, 2006).

This article argues for a correction of the emphasis on national and international reconciliation during peace-building processes. National and international violence obviously factor into the establishment of peace. However, focusing on these tensions at the expense of local conflicts is dangerous because local dynamics are important triggers of violence and can become disconnected from the national and international tracks. Nationally- and internationally-focused conflict resolution overlooks important local dynamics that threaten order - or prevent its implementation in the first place.

The article will start with an analytical framework, then I shall seek to locate sources at the local, national, and regional levels, of continued local violence during the transition. I emphasise the importance and distinctiveness of local agendas in the Congo as well as the local dimension of problems usually considered as purely national and regional (i.e., the status of the Rwandophone minority and the presence of the rebel Rwandan Hutu militias). Furthermore, I provide a brief overview of the situation in North Kivu and North Katanga, in order to document how the interlocking nature of these tensions caused violence to spread from one 
level to the other. I also demonstrate that, after a national and regional settlement was reached, some local conflicts over land, political power, and ethnic antagonism increasingly became self-sustaining, autonomous, and disconnected from the national and regional issues.

I draw on field observations in Kinshasa and the provinces of Katanga and the Kivus conducted between 2001 and 2006; document analysis; and more than 280 interviews conducted with Congolese politicians, military officers, diplomats, and civil society actors, victims of violence, staff of international organisations, and foreign observers - in the Congo, France, Belgium, New York, and Washington, DC. Given the substantial degree of political tension and uncertainty surrounding the themes of this article, and given the culture of secrecy pervasive in UN and diplomatic circles, most of the people I interviewed preferred to remain anonymous. For this reason, I reference only the data obtained through on-record interviews or in public sources. Unless otherwise indicated, the rest of the information presented in this article comes from the author's field observations and anonymous interviews.

\section{Analytical Framework}

The paucity of research on the impact of local violence on the viability of the peace processes constitutes a significant gap in the literature on conflict and conflict resolution. It raises such questions as: What are the local foundations of peace processes? How, precisely, do micro-local dynamics contribute to the failure of a national peace agreement?

Academics and practitioners often share the same flawed interpretation of conflict (Kalyvas, 2003). Most analysts perceive local dynamics 'as a mere (and rather irrelevant) local manifestation of the central cleavage' and local actors as mere 'replicas of central actors' (Kalyvas, 2003:481). Thus, academics who attempt to explain the success or failure of peace agreement implementation largely neglect the local preconditions for civil war settlements. They usually focus on macro-level parameters, such as the commitment to peace from a 'major or regional power' (Hampson, 1996; Downs \& Stedman, 2002), the role of international peacekeeping operations (Hampson, 1996; many contributors to Stedman, Rothchild et al. 2002; Walter, 2002), or the existence of signed peace agreements and power-sharing pacts (Hampson, 1996; Walter, 2002). Most of these studies also analyse each warring party as a monolith (Wood, 2002:5), overlooking the impact of intra-party disputes, which, in fact, have crucial consequences (Stedman, 1997; Zartman \& Rasmussen, 1997). They miss a critical point: local issues are specific and their dynamics are distinct from those at the national level (Kalyvas, 2003, 2006).

To illuminate the multiple layers and connections among conflicts at different levels, I build on Kalyvas's $(2003,2006)$ analysis that local and national dimensions of violence interact through two distinct mechanisms: cleavage and alliance. 'Cleavage' refers to the 'overarching issue dimension' - this is, for example, ideology, ethnicity, religion, or class - that links actors at the centre to actors on the ground (Kalyvas, 2003:476). 'Alliance' is a concept that links the central actors' quest for national power to the local actors' quest for local advantages. It 'entails a transaction between supralocal and local actors, whereby the former supply the latter with external muscle, thus allowing them to win decisive local advantage; in exchange the former rely on local conflicts to recruit and motivate supporters and obtain local control, resources, and information' (Kalyvas, 2003:486). 
In so doing, I challenge a prominent mono-causal interpretation of the Congolese conflict and transition to peace. Building on Collier and Hoeffler's 'Greed and Grievance' argument (2001), journalists and academics alike often reduce the motivations for violence in the Congo to a desire to exploit the massive Congolese natural resources (see for example Naidoo, 2003; Olsson, 2004, and Samset, 2002 for the war period and Global Witness, 2005 and Nest, 2006 for the transition). I consider not only explanations of violence based on resources (or other economic agendas) but also on political and social causes. I show that violence in the Congo, although motivated in part by 'greed' (the exploitation of natural resources), is also motivated by 'grievances': issues related to social status, identity, and political power.

\section{Identifying the Different Loci of Violence during the Transition}

\section{Regional Causes of Local Violence}

In March 2005, the UN Security Council denounced Rwanda's and Uganda's continuing involvement in supporting the armed groups responsible, among other things, for the perpetuation of violence in the Congo. In particular, Rwandan troops continued to operate in the Kivus and in 2004 the tactics of hit-and-run became common along the border regions (International Crisis Group, 2005:21-22; Institute for Security Studies, 2004; Romkema, 2004; UN Security Council, 2004). Three important incentives were at the root of the Rwandan involvement in the Congo during the transition: first, the threat posed by the continued presence of Rwandan Hutu militias; second, the problem of ethnic hatred against Congolese Rwandophones; and third, the appeal of the Kivus' mineral resources.

During the transition, armed groups affiliated with the Democratic Forces for the Liberation of Rwanda (Forces Démocratiques pour la Libération du Rwanda, or FDLR), a Rwandan rebel group composed mostly of ethnic Hutus, remained heavily present in the Kivus. ${ }^{1}$ They included combatants from the 1994 genocide as well as family members of the combatants, refugees, and political opponents forced to flee by Kagame's crackdown on opposition parties. The Rwandan government often complained about this continued FDLR presence in the Congo and emphasised the threat it posed to its country. Kigali, therefore, threatened several times - notably in November 2004 and in April 2005 - to invade the Congo again should Congolese and international actors fail to solve the FDLR problem. However, only a small number of FDLR had been active during the genocide and the relatively small group of FDLR combatants remaining in the Congolese forests did not seem to pose a real danger to Rwanda. Therefore, many Congolese and international observers claimed that Kigali complained about the FDLR presence in the Congo purely to find a pretext to come back into the Kivus in order to pursue Rwanda's true interests: protecting Rwandophones and exploiting the Congo's resources.

'Rwandophone' means Kinyarwanda-speaking people. In the Congolese context, the term is used to refer to Congolese of Rwandan ancestry (both Hutus and Tutsis). Although many of them descend from families who arrived in the Congo before or during the colonisation period, or shortly after independence (1960), their Congolese citizenship has been hotly contested for the past fifty years. These ethnic tensions have led to local ethnic massacres, such as in Masisi in 1993, and they were one of the reasons for the 1998 war. During the transition, the members of the Rwandophone community of the Congo were subject to considerable discrimination 
and abuse, and many Congolese groups contested their very right to live on Congolese territory. This hatred fed Rwanda's alleged concerns for a potential 'genocide' of Rwandophone communities. Several times during the transition notably after the May-June 2004 fighting in Bukavu and the August 2004 massacre in Gatumba - Rwanda threatened to go back into the Congo if the Congolese President, Joseph Kabila did not take appropriate measures to protect the Rwandophone minority and stop the anti-Rwandophone propaganda. The 'indigenous' Congolese - as ethnic groups that are native to the eastern Congo refer to themselves in order to emphasise that ethnic groups such as Rwandophone are foreign - felt deep resentment toward Rwanda because of its lengthy occupation of the eastern Congo. Thus these Rwandan threats reinforced the anti-Rwandophone feelings among the vast majority of the Congolese people and led to further discrimination and violence against Rwandophones.

Economic motivations also seemed largely to account for Rwanda's interest in the eastern Congo. UN and non-governmental organisations noted the discrepancies between the very limited mining resources of Uganda and Rwanda, and their massive exports of cassiterite, coltan, tin, and gold (Global Witness, 2005:4, 24-26; Pourtier, 2004:4; UN Security Council, 2005b: par 85-86). Global Witness's (2005) case study on cassiterite documented how the Rwandan state was involved in this illegal trafficking: first as the prime beneficiary (the state-owned company Redemi being the major exporter of tin and cassiterite); and second as an armed actor able to secure mining sites when necessary. In addition, Rwandan officials and civilians also benefited from the trafficking because of the 'important business links' they had developed with members of the Democratic Rally for Democracy - Goma (Rassemblement Congolais pour la Démocratie - Goma, or RCD-G), the rebel group that controlled most of the eastern Congo during the war and was transformed into a political party during the transition. This led to sporadic Rwandan involvement, aimed at influencing or supervising Congolese allies. The six-year conflict had enabled foreign countries to set up systems of exploitation that could continue functioning through Congolese proxies even after the Rwandan or Ugandan armies had withdrawn.

The combination of these security, political, and economic interests led Rwanda to actively support several armed groups responsible for local violence in the eastern Congo. At the end of 2003, Rwanda resumed military support to several Kivu militias (International Crisis Group, 2004). Furthermore, Rwandan officials supported the renegade military officers Laurent Nkunda and Jules Mutebusi during the May-June 2004 fighting in Bukavu and afterwards, helping them recruit soldiers and providing them with heavy arms and ammunition, uniforms, money, and a rear base in Rwanda to regroup and retreat when necessary (UN Security Council, 2004). Rwanda also helped the North Kivu Governor, Eugene Seruphuli (a Rwandophone affiliated with the RCD-G), arm Rwandophone civilians in Masisi and constitute additional local defence militias.

\section{National Causes of Local Violence}

If regional agendas continued to cause violence during the transition, national dimensions remained similarly influential. The Transitional Government was mostly characterised by a distrust among the representatives of the different 'components' of the transition institutions. These were the eight most powerful political or military groups at the outset of the civil war, and they had received an 
equal share of representation in the government, the parliament, and the national administration. The government did not work as a team to manage the transition and lead the country, but rather as competitive factions bent on overtaking one another and on enhancing the political, military, symbolic, and financial position of their own parties. Militarily, each component strived to maintain control over its former military assets under the umbrella of the newly unified army, the Armed Forces of the Democratic Republic of Congo (Forces Armées de la République Démocratique du Congo, or FARDC). The internal antagonisms were such that the government stopped functioning as an entity during the third year of the transition.

This continuation of high-level hostilities created dire local consequences. In the eastern provinces, the antagonisms between Kabila and the RCD-G fuelled the resistance of all former warring parties to the army integration process. The persistent distrust and lack of integration generated a highly volatile situation in those territories that continued to be controlled by troops affiliated with different factions, and led to both small-scale battles and several bouts of large-scale fighting. The local population was the first to suffer from this fighting: each armed group used violence to deter villagers from supporting some other faction.

The political struggle at the national level also fuelled the hatred against Rwandophones; this hatred remained a pervasive source of violence in the eastern provinces. In Kinshasa, newspapers every day disparaged the Rwandophone community and their political party, the RCD-G: both were presented as the source of the war and of all the problems in the transition, and they were depicted as the 'Trojan horse' of the abhorred Rwandese. Leaders from all side of the political spectrum defended a similar point of view, apparently for the sake of electoral advantage. Fuelling ethnic hatred spared politicians the need to develop real political platforms. Rwandophone-bashing was an easy way to show one's patriotism and to appeal to the majority of the Congolese population. This led to a vicious circle: existing ethnic tensions encouraged national politicians to use antiRwandophone rhetoric, which further stirred ethnic hatred, which was an important cause of local violence in the eastern Congo.

In addition, the struggle within the Transitional Government blocked the decisionmaking process. This, added to the strong interests most representatives had in stalling the transition process (to retain their positions of authority and continue to enrich their coffers, or to benefit from continued immunity from prosecution), caused the transition to progress at a very slow pace. It meant a continued absence of state authority in the east, especially in the rural areas. In the absence of state authority, the justice and police forces acted with impunity. Bias, corruption, and inefficiency were so widespread that these sectors lost all credibility with the Congolese people. At the same time, the lack of legitimate state authority in the east encouraged the continuation of violence, which seemed the easiest road to power and wealth. Thus civil as well as violent crime (including rape and kidnapping) persisted in many areas, unhindered by the non-functioning forces of law and order.

The conditions of impunity and the lack of legitimate state authority in the east also facilitated the illegal exploitation of resources. During the transition, the Congolese armed forces, the Rwandan rebel militias FDLR, the Congolese local self-defence militias called Mai Mai, armed forces of the former rebel movement RCD-G, as well as pro-Ugandan, pro-Rwandan, and criminal groups remained involved in illegal mining (Global Witness, 2005; International Crisis Group, 2005; Romkema, 2004; UN Security Council, 2005a, 2005b). Large quantities of cassiterite, coltan, gold, 
diamonds, and palm nut crossed the borders every day and evaded the tax authorities. This situation, in turn, fuelled the absence of state authority in the east: first, by reinforcing the reluctance of many local strongmen to work in good faith with the central authorities; and second, by depriving the Transitional Government of important resources that could have helped it extend its authority.

It also generated local violence in three different ways. First, national actors competed among themselves as well as with local and foreign armed groups (notably Mai Mai and FDLR) for the control of mining sites. This led to frequent fighting over the key mining areas of the Kivus (Global Witness, 2005:4, 8, 16). Second, illicit exploitation of resources enabled all armed groups to finance their war efforts, which further fuelled armed conflict (Staibano, 2005:3; UN Security Council, 2005c). Third, control of mining sites by national or local armed groups caused massive violence against the local population. Global Witness (2005:10) documents that in the mining areas of North and South Kivu, all armed groups committed 'colossal' abuses against non-combatants, including 'killing, rape, torture, arbitrary arrests, intimidation, mutilation, [and] the destruction or pillage of private property.' These abuses were 'integrally linked to natural resources ... as they were employed as methods by which to gain control either over resource-rich areas or over the ability to [exploit them].'

In addition, officials in Kinshasa embezzled funds earmarked for the army integration and for the soldiers' pay. As a result, the soldiers' commanders did not have the resources to remunerate their troops adequately or provide them with basic supplies and therefore encouraged them to make a living off the local population. Thus all soldiers (belonging to all components) continued to prey on the local population throughout the transition. This meant extorting the local residents, stealing all kinds of valuables in urban areas (money, mobile phones) and harvests or cattle in rural areas, and beating, raping, torturing, killing, or imprisoning those who refused to comply. Abuses by soldiers trying to make a living were so widely reported that they seemed to be the most common form of low-level violence in the east.

\section{Local Causes of Violence}

If regional and national antagonisms continued to generate high levels of violence at the local level, local conflict was also motivated by distinctly local causes. The main difference between the war period and the transition was that, during the transition, these local agendas became increasingly autonomous from the national and regional tracks.

In the east, at the grassroots level, the problem was not only 'the most obvious division, 'everybody against the [Rwandophones]' but also the 'hundreds of potential divisions, of local problems,' which were exploited by commanders and often erupted in violence. ${ }^{2}$ One of the main actors at the local level was the Mai Mai militias, local self-defence armed groups formed on the basis of ethnicity throughout the eastern Congo. The Mai Mai are officially considered a national actor (the Mai Mai 'movement' sent ministers, deputies, and senators to the transition institutions), but Mai Mai groups have never been unified under a single command structure. During the transition, just as during the war, the Mai Mai 'movement' remained a loose network of very different militias following various - and often competing leaders. 
In North Kivu, South Kivu, and North Katanga, a mosaic of alliances and counter alliances separated the numerous ethnic groups in each province. The clan and ethnic tensions were usually articulated in terms of social, economic, and political issues. Clannish, ethnic, political, and social identities remained extremely fluid during the transition and individuals often switched allegiance from one group to another as opportunities arose. The causes of the divisions were intertwined both with one another and with national and regional agendas.

Political antagonisms at the local level fuelled significant violence. Conflicts of succession continued to generate tensions similar to those that had existed before and during the war. During the transition, these were further complicated by the competition between new and traditional authorities. During the war, many traditional authorities (village, collectivity, or territory chiefs) had fled, either to escape ongoing violence or because an armed group had usurped their power. After the war, the return of the traditional authorities to their territories generated a high level of hostility.

In the Osso and Bashali collectivities (North Kivu), the Hunde population reportedly sided with the newly returned traditional chief, himself a Hunde, against the Hutu chiefs who had seized power during the war; in retaliation the Hutu chiefs committed 'a lot of abuses' against the supporters of their opponents. ${ }^{3}$ Such conflicts between new and traditional authorities were not limited to North Kivu. One of the main problems linked to the repatriation of refugees from Tanzania to South Kivu was the tension likely to arise with the return of traditional authorities to their area of origin. ${ }^{4}$ Similarly, in Nyunzu (North Katanga), people living in the camps for displaced people were not the lowest-ranking members of their communities but rather families of local traditional authorities (notably village and collectivity chiefs). Ordinary citizens had been allowed to go back to their villages, but when the chiefs tried to do so, the Mai Mai soldiers who had usurped their power threatened them and forced them to leave again. Articles in the press suggested that this situation was common throughout Katanga.

In addition to local conflict over traditional power, there was ethnic conflict over appointments in state institutions by transitional authorities. For example, in the Shabunda territory (South Kivu) in 2004, the Mai Mai General Padiri (himself a member of the Tembo ethnic group), who was recognised as a leading figure in the Mai Mai movement by the transitional authorities, reportedly appointed only Mai Mai Tembo to important military and administrative positions. This led to several small-scale fights between the Mai-Mai Tembo and the Mai-Mai Rega, until the Mai Mai Rega retaliated by chasing the Mai Mai Tembo from Shabunda territory.

In most cases, such political tensions interfaced with economically motivated hostilities. Political power often guarantees access to land and economic resources, while access to wealth means, in turn, the availability of resources to buy arms and reward troops and to secure political power. In particular, the land problems that had led to massive local violence before and during the war (Mamdani, 2001; Van Acker \& Vlassenroot, 2000; Willame, 1997) remained salient in the eastern Congo and often constituted the grassroots dimension of local conflicts (UN Mission in the Congo [Mission de l'Organisation des Nations Unies au Congo, MONUC] 2004).

In South Kivu, land issues were usually the most important source of conflict in rural areas and further problems were expected with the return of refugees. ${ }^{5}$ In North $\mathrm{Kivu}$, land problems were 'the main source of local conflicts' in Masisi and an 
important source of tension between RCD-G and Mai Mai groups stationed in Walikale in early 2004.6 In North Katanga, the Bembes reportedly attempted to take over land in Holoholo and Kalanga areas. Local tensions over land sometimes erupted into open fighting, such as in Walikale (North Kivu) in June 2004, Bwerema (South Kivu) in December 2004, and Katogota (South Kivu) in November 2005. They also greatly impeded the peaceful return of refugees and displaced persons because those in control of the land after the war threatened to use force to avoid giving it up.

As noted above, competition among fragmented militias for the control of natural resources also remained a major cause of violence in the Kivus and North Katanga. Finally, the need to find the means of survival, and the lack of social opportunities, which had pushed many civilians to enrol in militias during the war (Van Acker \& Vlassenroot, 2000), remained salient during the transition. Before the war, most of the Congolese population had faced massive poverty and unemployment. In the east, this situation deteriorated further during the war. Children and teenagers who had grown up during the war had not received proper schooling and thus were not well-prepared for pursuing peaceful and productive activities. Land remained scarce, so young people could not easily acquire fields for farming, and the economic infrastructure was nonexistent. Outside intervention in the east continued to focus on humanitarian issues, and very few development projects were funded in the eastern provinces. In this context, being part of a militia remained the most profitable option.

Militias also remained the only source of social mobility. Individuals and groups such as the youth and the pygmies - who, because of the war, had attained a status that was previously denied to them, had strong incentives to perpetuate the violent situation that had enabled them to reach a higher social position. Similarly, many Mai Mai chiefs knew that, should peace return to the Congo, they would lose their status as all-powerful, kinglike leaders and become once again mere soldiers - often ill-trained and illiterate. This was one of their main motivations for refusing to be integrated into the army. This persistent violence compounded the danger faced by those perceived as having wronged their neighbours or their communities during the war. It allowed the threat of retaliation to remain the main reason why, two years after the beginning of the transition, many refugees and displaced persons had failed to return to their home villages in the Kivus and North Katanga. ${ }^{7}$

\section{Local Dimensions of the FDLR Problem}

These economic and political issues often motivated local alliances with the Rwandan rebel militias, the FDLR. Given the number of atrocities for which the FDLR is responsible, its leaders' claims that their troops were often well integrated in the Kivus may have sounded like mere propaganda. However, the FDLR did benefit from the support of many local strongmen.

The Mai Mai, their allies from the war period, often continued to collaborate with the FDLR in both the Kivus during the transition - hiding them, conducting business with them, or enlisting them in their factional fighting against other Mai Mai groups. During the transition, the FDLR even enrolled new allies: soldiers of the Congolese armed forces previously loyal to President Joseph Kabila or to the former rebel leader Jean-Pierre Bemba. A UN official working with the FDLR (interviewed in 2005) reported that these Congolese soldiers were 'afraid of the FDLR' and therefore refused to attack them. Because they also were not paid and were poorly disciplined, they were easily bribed by the FDLR into assisting them in taxing and looting the 
Congolese population (such as in Shabunda territory) or in turning a blind eye to their presence (such as in the South Kivu territories of Kilembwe and Lemera).

In addition to armed forces, local administrative authorities throughout the eastern Congo also collaborated with the FDLR. In the Lubero and Walikale territories (North Kivu), for example, the authorities of the RCD-Kisangani/Liberation Movement largely tolerated the presence of FDLR members, provided they refrained from raping and killing while they looted villages. In South Kivu, there was important collusion and economic ties between FDLR and local authorities. In places like Rutchuru, Lemera, and Kilembwe, Congolese inhabitants reportedly accepted the FDLR living on their territory as long as they refrained from harassment.

The presence of FDLR in the Congo, which usually has been presented as a national or regional problem, was thus very much grounded in local dynamics, which reinforced national and regional interaction. Local alliances were key to perpetuating the FDLR presence on Congolese territory and the violence associated with it. To a high ranking Rally-FDLR official (2005), Rwandan Hutu refugees 'would not have been able to survive' without the good relationships they had developed with the local population. FDLR groups were too small and too divided internally; they could not have remained on Congolese territory if they had been required to survive on their own while fighting back all Congolese military forces. On the contrary, support by local armed groups enabled the Rwandan combatants to recruit allies, to fight their opponents, and to hide from the Congolese armed forces (usually former members of the Congolese Rally for Democracy) and UN troops determined to attack them. That local authorities tolerated the FDLR on mining territories also enabled the Rwandan militias to find the economic resources they needed to buy arms and continue fighting. ${ }^{8}$ Moreover, this local collaboration enhanced the quality of life for the FDLR on Congolese territory and therefore diminished their incentives to peaceably return to Rwanda. Support by local authorities, local forces, and sometimes local populations allowed FDLR forces to live near Congolese villages. In selected places such as Rutchuru, Shabunda, and Kilembwe, this enabled FDLR families to trade goods and services with the surrounding population. In other places, it provided the FDLR with the opportunity to live off the surrounding Congolese population through looting. Kidnappings, rapes, tortures, and massacres accompanied their raids on Congolese villages.

\section{Local Dimensions of the Rwandophone Issue}

Contrary to a commonly held belief, the problem of the Rwandophone minority status, which had the potential of jeopardising the regional and national peace settlements, also carried distinctively local stakes. Before the war, the Rwandophone problem was rooted in local conflicts around land and traditional power (Mamdani, 2001; Willame, 1997). During the transition, Rwandophones' claims on traditional political power - and their associated claims on land - continued to fuel antiRwandophone sentiments and to generate violence. Tensions were especially high in provinces where the Rwandophones constituted the largest ethnic group and thus could easily seize local power, such as in Masisi. In South Kivu, Rwandophones were a minority in all territories but their claim of entitlement to traditional representation also met with large resistance. There, the reason was that during the war the rebel movement Congolese Rally for Democracy - Goma had carved up a few territories such as Minembwe where Banyamulenges (Rwandophones native to the South Kivu province) were the majority and could therefore rule the area. During the 
transition the Banyamulenges refused to abide by the requests of the 'indigenous' communities to return to the pre-war territorial arrangements.

All throughout South Kivu, these political and economic motivations were multiplied exponentially by the departure of Banyamulenges from Uvira and Bukavu in June 2004, after fighting took place there between Rwandophone and troops of the newly unified Congolese Armed Forces. Those who fled vacated the high positions and nice houses they had acquired during the war. 'Indigenous' Congolese took over these jobs and houses, refused to restore them to the Banyamulenges who returned in late 2004, and tried to discourage the refugees from coming back and threatening their new wealth and authority. Given these local political and economic stakes, the return of the Banyamulenges who had fled generated many incidents of violence in 2004 and 2005. The most publicised one took place in September 2004 when, after 160 Banyamulenge refugees (mostly women and children) were massacred in a refugee camp in Gatumba (Burundi), reportedly by Congolese militiamen, hundreds of Banyamulenge refugees tried to return to the Congo from Burundi. They were blocked at the border for several days and obliged to stay in the 'neutral zone' between the two countries. The first group that succeeded in re-entering the Congo was stoned by an angry mob that reportedly had been organised by local authorities. After that incident, a few Banyamulenges trickled back into South Kivu, but many stayed in Burundi for over a year, afraid to go back.

In sum, during the transition, just as during the war, local violence was motivated not only by top-down causes (regional or national) but also by bottom-up agendas, whose main instigators were villagers, traditional chiefs, community chiefs, or ethnic leaders. The resulting violence was not coordinated on a large scale, but rather it was the product of fragmented, micro-level militias, who tried to advance their own agenda at the village or district level. The following section illuminates the relationships between regional, national, and local dimensions of violence in two eastern provinces.

\section{Interaction between Local, National \& Regional Motivations: Understanding the Joint Production of Violence}

There was an interaction between the local and the national and regional levels namely alliances between local actors and national and regional actors. However, throughout the transition, local actors and local agendas became increasingly autonomous and disconnected from the national and regional tracks. In North Kivu, contrary to the commonly held belief, local cleavages remained an important, autonomous source of violence. In North Katanga, local agendas were disconnected from the national and regional tracks and they proved more influential than national and regional issues in generating armed conflict. They led to clashes that neither national nor regional actors could stop, which in turn could have jeopardised the regional and national settlements.

\section{North Kivu: Master Cleavages \& Local Alliances}

During the transition, North Kivu (see map over) was marred by the combination of tensions among its eight ethnic communities - mostly caused by land and citizenship issues - and by conflicts between the five armed groups present in the province (Democratic Rally for Democracy-Goma or RCD-G, Democratic Rally for 
Democracy-Kisangani/Liberation Movement or RCD-K/ML and government forces, Democratic Forces for the Liberation of Rwanda or FDLR, Mai Mai, and local defence forces). Most sources have characterised the violence in terms of the master ethnic cleavage (Rwandophones versus other ethnic communities), neatly superimposed and running along the same dividing line as the political cleavage (Kabila versus RCD-G). This reading of the conflict overlooked the key role of local tensions in generating violence.

After large-scale fighting took place around Bukavu in June 2004 and the RCD-G lost control of the South Kivu province, and while the political struggle between Kabila and the RCD-G continued unabated throughout the whole Congo (in particular in Kinshasa), the military conflict between these two enemies continued in one last place: North Kivu. The 'Petit Nord' (the southern part of North Kivu) remained the last stronghold of the RCD-G. The former rebel movement maintained absolute control there. The governor (Eugène Seruphuli) and the regional military commander were both RCD-G officials. Up until 2006, rank and files of the Congolese armed forces were not enlisted from each component but instead were exclusively former RCD-G soldiers. They were supported by the three-thousand-strong Local Defence Forces, a predominantly Hutu militia that governor Seruphuli created during the war and that Rwandan forces trained. North Kivu's financial revenues remained in the province instead of going to the capital, and pro-RCD-G communities continued to hold the economic and social power of the province. As a result, from the Bukavu crisis onward, national politicians - except for those belonging to the RCD-G - thought of North Kivu as the exception: the province least integrated into the transition process and the last holdout, the place Kabila needed to take control of in order to unify the rest of the country. The regional dimension was also present - although less so than during the wars. Rwanda reportedly supported the RCD-G with its financial, military, and political might, and occasionally engaged in fighting against the ethnic Nandes, the Mai Mai, and the rebel Rwandan militias alongside RCD-G troops.

In addition to the soldiers that it progressively managed to send to North Kivu, the Kabila government's strength in its struggle against the RCD-G in this province came in large part from the allies it had there: the Democratic Rally for DemocracyKisangani/Liberation Movement or RCD-K/ML, which kept the RCD-G busy on the northern front (along the same front line as during the war); and the Mai Mai, which fought against the RCD-G from within its area of control. Importantly, during the transition both of these allies were anti-RCD-G for provincial and local reasons rather than because of any convictions about the master conflict between Kabila and the RCD-G.

Indeed, since colonisation, North Kivu had progressively seen a strong polarisation between its two most populous ethnic groups, the Banyarwandas (Rwandophones from the North Kivu province) and the Nandes, over the control of the province (Willame, 1997). During the war, the elites of these competing ethnic groups each controlled half of the province and allied themselves with different warring parties - the RCD-K/ML and Kabila for the Nandes, the RCD-G for the Banyarwandas. During the first months of the transition, the antagonism had reached such a point that the Banyarwandas and Nandes suspected each other of harbouring plans to eradicate the other. In May 2004, the province was finally reunified administratively and put under the leadership of Eugene Seruphuli. However, this did not assuage the tensions between Banyarwandas and Nandes. On the contrary, members of non- 
Rwandophone ethnic groups living in Goma complained that the RCD-G's rule had a strong ethnic flavour, and it continued to be associated with Banyarwanda domination. ${ }^{9}$ As a result, up until the end of the transition, Nande Mai Mai groups remained extremely active in the 'Grand Nord' for fear of a potential Banyarwanda invasion from the south. Despite administrative reunification, the front line between RCD-G and RCD-K/ML forces (allied with Rwanda's and Kabila's troops, respectively) remained active. Numerous skirmishes took place there in 2004, 2005, and 2006, and they erupted in a large-scale confrontations around Kanyabayonga in December 2004, Rutchuru in January 2006, and Sake in August 2006.

In addition, Kabila could also count on local tensions between 'indigenous' and Rwandophone communities to recruit local allies, both political (as in the Civil Society party) and military (as in the Mai Mai militias) to fight against the RCD-G from within its area of control. In Masisi and Rutchuru, for example, Civil Society representatives and local militias had two reasons for fighting against anything perceived as part of a Rwandophone movement (MONUC, 2004). First, the Hundes and the Nyangas felt that they were the only communities with a rightful claim on traditional (and political) representation. Although the Hutus were the majority population of the Masisi territory and demanded the right to adequate representation at the political and traditional levels, the Hundes and Nyangas saw them as 'immigrants' who had arrived during the colonisation or after independence and therefore had no legal claim on traditional power. As explored above, this led to major tensions regarding who could be named chief of a village or a collectivity, such as in the Osso and Bashili collectivities.

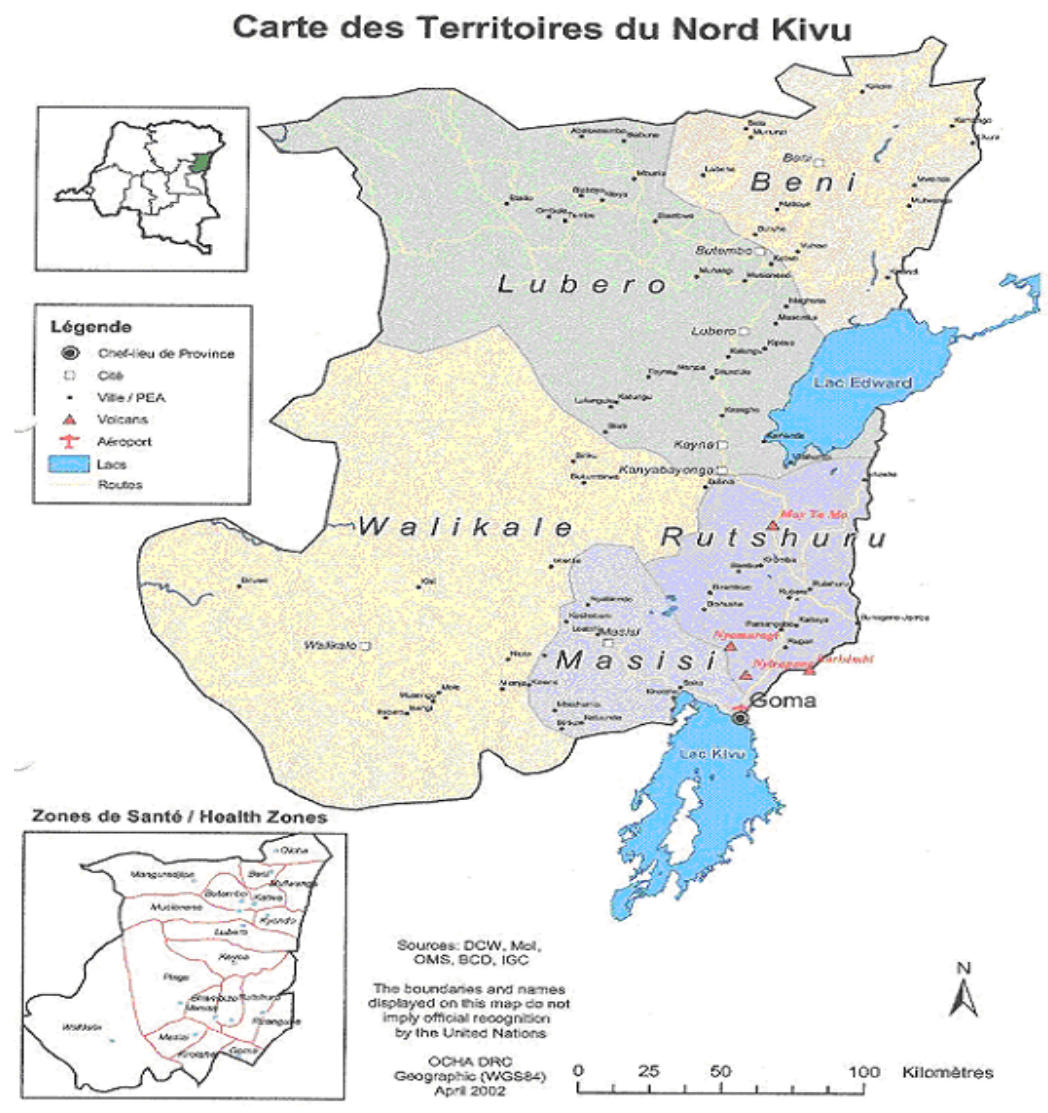


Second, Rwandophones (mostly Tutsis) owned about 80 per cent of the land as a result of transactions they had made under Mobutu. However, the Hundes and the Nyangas claimed that the land was traditionally theirs: Mobutu should not have been allowed to sell it because it belonged to traditional authorities. The issue of land ownership was further complicated by the fact that many Tutsis had fled Masisi in the 1990s to escape the ongoing massacres, and either had abandoned their land or sold it at an artificially low price. When they came back after the 1996 and 1998 wars, they found their lands occupied and reportedly took all of it back, by force if necessary, including the land that had been sold legitimately. ${ }^{10}$

These local antagonisms over political and economic issues were carried onto the military stage, particularly the conflict between the Mai Mai (allied with FDLR) and both the Local Defence Forces militia and the RCD-G. The Mai Mai represented the 'indigenous' communities, whereas the RCD-G and Local Defence Forces were accused of siding with the Hutus and the Tutsis. Fighting became more frequent and more violent after the 2004 Bukavu crisis, which generated a complete breakdown of trust between the RCD-G and the Mai Mai. In October 2004, the situation in Masisi became so tense that there was once again a real front line within the province, with both groups committing abuses against people crossing to the other side.

Local agendas regarding traditional power or land, which led to hostilities at the provincial (Nandes versus Rwandophones) and village (Hutus or Tutsis versus other communities) levels, were therefore as influential as national and regional cleavages in generating violence. However, local conflicts were easily reinterpreted in light of the ethnic and political cleavages, and thus North Kivu politics appeared to be dominated by these master cleavages. In contrast, in North Katanga the master cleavages carried very little weight and the local agendas could hardly be interpreted in light of them.

\section{North Katanga: Uncontrolled Militias Rejecting National Control}

The continued insecurity in North Katanga (see map below) was indeed attributable mostly to local factors, which were disconnected from the national cleavages. At first glance, it seemed that Kabila had asserted his control over the province. General Dunia, posted at the southern tip of South Kivu, reportedly served to protect Katanga from enemy attacks from the north should Rwandans resume their attack in the Kivus. Kabila had apparently ensured the loyalty of the administrative and military authorities in the region, either by replacing them or by letting them switch sides. In 2004, the Congolese armed forces stationed in the region were supposedly a mixture of former RCD-G soldiers, Mai Mai groups, and governmental forces. However, this alleged governmental control was a fallacy. In reality, state authority was absent from North Katanga. Even if the security situation there showed a tremendous improvement compared to the war period, many areas in the territory remained plagued by micro-local, uncontrolled armed groups (mostly former Mai Mai), who spent most of their time harassing the civilian population and fighting against the FARDC or among themselves.

During the transition, a rupture indeed appeared between the North Katanga Mai Mai and the Transitional Government. Katangan Mai Mai thought that they had not been adequately rewarded for having saved Lubumbashi, the capital of the Katanga province and the second largest city of the Congo, from the RCD-G and Rwandan troops during the war. In addition, Mai Mai members of the Transitional Government came from the Kivus and Maniema, so Katangan Mai Mai did not feel 
either represented by them or bound by the agreements they signed (including the agreement to integrate Mai Mai troops into the Congolese armed forces). The Mai Mai demand for integration in the Congolese armed forces was therefore far less in Katanga than in the Kivus. The problem was further compounded by the reluctance of Kabila's component to integrate the Mai Mai groups active on the government side of the frontline during the war into the Congolese armed forces. To Kabila's followers, these Mai Mai groups had fought government forces instead of the foreign invaders; they were therefore enemies. ${ }^{11}$

The top military commanders of the Congolese armed forces first tried to convince the Mai Mai to join the unified army, but they had limited success. Thus they changed strategy in late 2004 and organised military operations in many Katangan territories against the remaining un-integrated forces. It led to additional skirmishes and their associated cortege of insecurity and violation of human rights. It also heightened the fallout between the Mai Mai and the Congolese armed forces. The consequences were two-fold. First, in late 2004 and 2005, journalists and humanitarian workers reported constant fighting between the Congolese armed forces and Katangan Mai Mai, notably around Mitwaba, Kongolo, and Malemba Nkulu. Second, state authority totally collapsed in North Katanga, which enhanced the impunity for human rights violations and illegal actions, and therefore further facilitated violence by all armed groups.

In addition to the tensions between the Mai Mai and the Congolese armed forces, frequent fighting took place among the Mai Mai militias over a combination of political, economic, and ethnic antagonisms. At the territory, or village level, Mai Mai groups strived to maintain their power over their former areas of control in order to dominate the administrative and traditional powers, manage mineral-rich areas, divert taxes, and impose all kinds of fines on the population. These political and economic agendas interacted with numerous ethnic tensions: hatred of pygmies and 'Kasaian' groups remained widespread while, in each district, the amount of other clan, tribal, or ethnic rivalries continued to simmer away. Unconfirmed information also held that provincial and national actors enhanced these local antagonisms. The result was that fighting among Mai Mai militias and abuses against the local population reached such a point that, near Mitwaba, a new 'popular self defence force' was created in order to protect villagers against the Mai Mai - which was ironic because, initially, the Mai Mai militias were born as popular self defence forces tasked with protecting their villages.

During the transition, local agendas were therefore the prime causes of continued violence in North Katanga. National cleavages had very little influence: RCD-G military and administrative authorities had either disappeared or switched sides, and there were no Rwandophones to harass. Regional cleavages were similarly non-influential because foreign armed groups had left the province. The only form of outside influence on North Katanga was an alleged control or manipulation of Mai Mai groups by Kabila and his advisors. Several UN and diplomatic interviewees claimed that Kabila's advisors manipulated local antagonisms in order to pit Mai Mai groups against one another, but they could not articulate clearly the advisor's motivations for this manipulation. Katangans usually identified the desire to benefit from the illegal exploitation of resources as the main cause for national involvement in their province. However, none of my interviewees could provide any concrete evidence to support their claims. 


\section{Conclusion}

My analysis suggests that peace builders involved in the Congolese transition should have addressed local violence for two main reasons. First, the humanitarian cost of local antagonisms that turned violent was staggering. Second, the neglect of local issues could lead only to incomplete and unsustainable peace settlements.

Local manifestations of violence, although often related to national or regional struggles, were also precipitated by distinctively local problems. These included conflict over land, mineral resources, traditional power, local taxes, and the relative social status of specific groups and individuals. Even issues usually presented as regional questions (such as the FDLR problem) or national ones (such as ethnic tensions with Congolese Rwandophones) had significant local components, which fuelled and reinforced the regional and national dimensions.

Local, national, and regional dimensions of violence remained closely interlinked in most of the eastern Congo. Local agendas provided national and regional actors with local allies, who were crucial in maintaining military control, continuing resource exploitation, and persecuting political or ethnic enemies. Local tensions could also jeopardise the national and regional reconciliation: for example, by motivating violence against the Rwandophone minority or allowing a strong FDLR presence in the Kivus. In addition, during the transition, some local conflicts became autonomous from the national and regional tracks, most notably in South Kivu and North Katanga. There, local disputes over political power, economic resources (especially land and mining sites), and social status led to clashes that no national or regional actors could stop. Thus, addressing local issues was key to ending violence and to ensuring the stability of the national and regional settlements. Peace building action was required not only at the national and regional level but also locally.

Concretely, international actors could include local conflict in peace processes by slightly modifying their usual approach to peace building. In all war and post-war contexts, policy-makers should commission applied research to illuminate both the distinctive local dynamics of violence and the local underpinnings of national (and potentially international) tensions. Based on this analysis, international actors should step up their interventions on local conflict in two different but complementary ways. First, donors should increase the funding available for international and local non-governmental organisations specialised in local conflict resolution, either by modifying their assistance priorities or by increasing their aid budgets. To ensure that the additional money funds efficient conflict-resolution programs, donors should build up structures that can identify reliable local peace builders in the provinces as well as in the capital. Second, whenever civil society actors are illequipped to address the local tensions (such as when violence is caused by military antagonisms), international political and military actors should step in. The intervention of diplomats and political or military UN staff in local conflict would, on the one hand, deter local warlords and, on the other hand, signal to these warlords a possibility for assistance - and therefore increase the estimated peace dividends.

Séverine Autesserre is an Assistant Professor of Political Science at Barnard College, Columbia University. Prior to that, she worked as a humanitarian worker in several war and post-war situations, including the D.R. Congo in 2001 and 2003 and is 
currently finalising a book entitled Local Violence, International Indifference? The Failure of Peace Building in the Congo. Parts of this article were previously published in the African Studies Review (49:3, 2006); e-mail: severine@nyu.edu

\section{Endnotes}

1. In this article, I use FDLR to refer to all Hutu refugees based in the eastern Congo, including the few not associated with the FDLR movement.

2. Citations from an author's interview with Hans Romkema, head of Life and Peace Institute, Bukavu, 2004.

3. Author's interview with Azile Tanzi, head of mission of Campagne Pour la Paix, Goma, 2005.

4. Author's interview with Jean-Charles Dupin, Humanitarian Advisor for the UN Office for the Coordination of Humanitarian Affairs, Bukavu, 2005.

5. Author's interview with Professor Séverin Mugangu Matabaro, Universite Catholique de Bukavu, 2006.

6. On Masisi: author's interview with Anders Vatn, head of Mission for the Norwegian Refugee Council, Goma, 2005.

7. Author's interview with Vatn, 2005.

8. The incentive to stay in the Congo was all the stronger because the dictatorial nature of the Kigali regime and its harsh treatment of political opponents gave Rwandan Hutu refugees in the Congo little hope for livable conditions in Rwanda. It was further reinforced by the harsh discipline implemented by FDLR top commanders, who would lose the basis of their power if FDLR combatants and civilians left the Congo; many leaders intimidated and sometimes killed the potential deserters they had identified in their ranks.

9. Author's interview with Tanzi, 2005.

10. Author's interview with Tanzi, 2005.

11. Author's interview with Nawezi Karl, University of Kinshasa, October 2004.

\section{Bibliography}

Autesserre, Séverine (2006), 'Local Violence, International Indifference? Post-Conflict 'Settlement' in the Eastern D.R. Congo (20032005), Ph.D. diss., New York University.

Collier, Paul \& Anke Hoeffler (2001), 'Greed and Grievance in Civil War' in Oxford Economic Paper (56): 663-695.

Downs, Georges \& Stephen John Stedman (2002), 'Evaluation Issues in Peace Implementation' in Ending Civil Wars. The Implementation of Peace Agreements, Stephen John Stedman, Donald Rothchild \& Elizabeth Cousens (eds.), London: Lynne Rienner: 43-69.

Global Witness (2005), Under-Mining Peace. Tin: The Explosive Trade in Cassiterite in Eastern DRC, Washington, DC: Global Witness.

Hampson, Fen Osler (1996), Nurturing Peace: Why Peace Settlements Succeed or Fail, Washington, DC, United States Institute of Peace Press.
Institute for Security Studies (2004), Growing Instability in the Kivus: Testing the DRC Transition to the Limits, Pretoria: Institute for Security Studies.

International Crisis Group (2004), Back to the Brink in the Congo, Brussels: International Crisis Group Africa Briefing; (2005), The Congo's Transition Is Failing: Crisis in the Kivus, Brussels: International Crisis Group.

International Rescue Committee (2004), Mortality in the Democratic Republic of Congo: Results from a Nationzwide Survey. Conducted AprilJuly 2004, New York: International Rescue Committee and Burnet Institute.

Kalyvas, Stathis N. (2003), 'The Ontology of 'Political Violence': Action and Identity in Civil Wars.' American Political Science Review (1-3): 47594; (2006), The Logic of Violence in Civil War, New York, Cambridge University Press. 
Mamdani, Mahmood (2001), When Victims Become Killers: Colonialism, Nativism, and the Genocide in Rwanda, Princeton: Princeton University Press.

Naidoo, Sagaren (ed.) (2003), The War Economy in the Democratic Republic of Congo, Braamfontein, South Africa: Institute for Global Dialogue.

Nest, M., F. Grignon et al. (2006), The Democratic Republic of Congo. Economic Dimensions of War and Peace, Boulder: Lynne Rienner.

Olsson, Ola (2004), 'Congo: The Prize of Predation' in Journal of Peace Research 41(3): 321336.

Pourtier, Roland (2004), L'économie minière au Kivu et ses implications régionales (version provisoire): Rapport suite à une mission au Nord Kivu, au Sud Kivu, et au Rwanda, Paris: OCDE-Initiative for Central Africa / Initiative pour l'Afrique Central.

Romkema, Hans (2004), Update on the DRC Transition: The Case of the Kivu Provinces, Pretoria: Institute for Security Studies.

Samset, Ingrid (2002), 'Conflict of Interests or Interests in Conflict? Diamond and War in the DRC' in Review of African Political Economy, 9394: 463-480.

Staibano, Carina (2005), Enhancing the UN Capacity. Part 2: The Democratic Republic of Congo: Enhancing UN Peacekeeping Capacity - Some Operational Aspects, Department of Peace and Conflict Research, Uppsala University.

Stedman, Stephen John (1997), 'Spoilers Problems in Peace Processes' in International Security 22(2): 5-53.

Stedman, Stephen John, Donald S. Rothchild \& Elizabeth M. Cousens (eds.) (2002), Ending Civil Wars: the Implementation of Peace Agreements. Boulder: Lynne Rienner.

Synergie Vie (2004), Mémoire Sur Les Entraves Au Rappatriement Des Groupes Armés Hutu Étrangers Dans Le Kivu. Bukavu (D.R. Congo): Synergie Vie.

UN/MONUC (2004), 'Kivu Strategy and Kivu Offices Action Plans', Kinshasa (D.R. Congo): United Nations.

UN Office for the Coordination of Humanitarian Affairs (2003-2007), Monitoring De La Situation Humanitaire En RDC, Kinshasa (D.R. Congo): UN Office for the Coordination of Humanitarian Aid.
UN Security Council (New York) (2004), Report of the Secretary-General to the Security Council on the Arm Embargo in the Democratic Republic of Congo; (2005a), Nineteenth Report of the SecretaryGeneral on the United Organization Mission in the Democratic Republic of Congo; (2005b), Report of the Secretary-General to the Security Council on the Arm Embargo in the Democratic Republic of Congo; (2005c), Resolution 1592 (2005); (2005d), Sixteenth Report of the Secretary-General on the United Organization Mission in the Democratic Republic of Congo.

Van Acker, Frank \& Koen Vlassenroot (2000), 'Youth and Conflict in Kivu: "Komona Clair"', Journal of Humanitarian Assistance, www.jha.ac.

Walter, Barbara F. (2002), Committing to Peace: the Successful Settlement of Civil Wars, Princeton: Princeton University Press.

Willame, Jean-Claude (1997), Banyarwanda Et Banyamulenge: Violences Ethniques Et Gestion De L'identitaire Au Kivu. Paris: L'Harmattan.

Wood, Elisabeth J. (2002), 'Civil Wars: What We Don't Know', paper presented at the workshop, Democratization After War: State-ofthe-Art Thinking about Governance and Peace-building, Tinas J. Watson Jr. Institute for International Studies, Brown University, Providence, Rhode Island.

Zartman, I. William \& J. Lewis Rasmussen (1997), Peacemaking in International Conflict: Methods and Techniques, Washington, DC: United States Institute of Peace Press. 


\section{Glossary}

Banyamulenge: Congolese of Rwandan ancestry living in South Kivu.

Banyarwanda: Congolese of Rwandan ancestry living in North Kivu.

FARDC: Forces Armées de la République Démocratique du Congo / Armed Forces of the Democratic Republic of Congo (integrated national army during the transition).

FDLR: Forces Démocratiques pour la Libération du Rwanda/Democratic Forces for the Liberation of Rwanda (Rwandan rebel group composed mostly of ethnic Hutus based in the eastern Congo).

Kabila, Joseph: Son of late president Laurent-Désiré Kabila. President of the Congo since 2001.

Mai Mai: Local militias formed on ethnic basis throughout the eastern Congo.

MONUC: Mission de l'Organisation des Nations Unies au Congo/United Nations Organization Mission in the Congo.

RCD-G: Rassemblement Congolais pour la Démocratie - Goma/Congolese Rally for Democracy Goma (main rebel group during the 1998 war, controlled most of the eastern Congo. Transformed into political party during the transition).

RCD-K/ML: Rassemblement Congolais pour la Démocratie - Kisangani / Mouvement de Libération Congolese Rally for Democracy - Kisangani / Liberation Movement (small rebel group during the 1998 war, controlled part of North Kivu. Transformed into political party during the transition).

Rwandophones: Kinyarwanda-speaking people. In the Congolese context, term used to refer to the Congolese of Rwandan ancestry (both Hutus and Tutsis).

\section{SPECIAL ISSUE State Failure in the Congo}

by Theodore Trefon, Saskia Van Hoyweghen, $\mathcal{E}$ Stefaan Smis (guest editors)

ROAPE, Volume 29, Number 93/94

(Sep/Dec 2002) 